\title{
Ưu tiên đầu tư và quan tâm của các bên đối với lînh vực các hoạt động bảo vệ và phát triển rừng tại Việt Nam giai đoạn 2011- 2019
}

\author{
Phạm Thu Thủy, Đào Thị Linh Chi, Hoàng Tuấn Long, Ngô Hà Châu, Hoàng Thị Uyên, Trần Ngọc \\ Mỹ Hoa, Hoàng Minh Hiếu, Nguyễn Văn Diễn
}

\section{Thông điệp chính}

- Tóm lược chính sách này cho thấy các ưu tiên đầu tư của các bên có liên quan trong lĩnh vực bảo vệ và phát triển rừng giai đoạn 2011- 2019 tập trung vào 16 lĩnh vực chính: 1. Bảo tồn; 2. Gia tăng trữ lượng các-bon (vd. tái sinh rừng); 3. Khai thác rừng bền vững (vd. cấp chứng chỉ); 4 . Trồng mới và tái trồng rừng; 5 . Giảm phát thải đất nông nghiệp (vd. nông nghiệp xanh, cam kết không phá rừng); 6 . Thiết kế chính sách và chương trình REDD+ cấp quốc gia; 7 . Thiết kế chính sách và chương trình REDD+ cấp tỉnh; 8. Thực hiện chương trình REDD+ (MRV, biện pháp đảm bảo an toàn); 9 . Thí điểm REDD+; 10. Quyền sở hữu; 11. Bảo tồn đa dạng sinh học; 12. Xóa đói giảm nghèo; 13. Quản trị lâm nghiệp (khai thác bất hợp pháp, chống tham nhũng); 14. Lâm nghiệp cộng đồng, đồng quản lí; 15. Thích ứng với biến đổi khí hậu; 16. Buôn bán và thương mại các-bon. Các ưu tiên đầu tư nguồn lực của các bên dành cho 16 lĩnh vực này phần lớn tăng lên và mở rộng theo thời gian để bắt kịp với xu thế phát triển của ngành lâm nghiệp trên thế giới. Các hỗ trợ ưu tiên của các bên tạo điều kiện thuận lợi để Việt Nam thử nghiệm và tiên phong trong nhiều lĩnh vực chính sách và công nghệ mới.

- Các lĩnh vực như xoá đói giảm nghèo, quản trị lâm nghiệp và bảo tồn đa dạng sinh học, giảm phát thải từ sử dụng đất lâm nghiệp và khai thác rừng bền vững, thiết kế và thực hiện $\mathrm{REDD}+$ nhận được sự quan tâm cao nhất của các bên. Vấn đề về quyền sở hữu và khai thác rừng bền vững tuy có mức ưu tiên tăng lên hạn chế nhưng vẫn là vấn đề ưu tiên đầu tư then chốt của phần lớn các tổ chức được khảo sát. Mức độ ưu tiên và đầu tư của các bên dành cho lĩnh vực trồng mới rừng và tái trồng rừng đã giảm dần theo thời gian.

- Mặc dù các ưu tiên hỗ trợ tài chính và kĩ thuật từ 2011 cho tới 2019 đã tạo một số điều kiện thuận lợi cho ngành lâm nghiệp phát triển, các ưu tiên hiện nay của các bên cũng cho thấy nhiều lĩnh vực (ví dụ: lâm nghiệp cộng đồng, mua bán thương mại các-bon, chế biến lâm sản) còn đang bị bỏ ngỏ cũng như chưa được đầu tư tương xứng với tiềm năng và vai trò của lĩnh vực này.

- Định hướng của Luật Lâm nghiệp là phát triển ngành lâm nghiệp toàn diện theo chuỗi từ quản lý bảo vệ, phát triển cho đến sử dụng rừng và chế biến thương mại lâm sản. Tuy nhiên, các lĩnh vực quan tâm và ưu tiên của các bên liên quan cho đến nay tập trung chủ yếu cho khâu quản lý và bảo vệ rừng. Phát triển ngành lâm nghiệp toàn diện và bền vững cần có sự ưu tiên đầu tư cho tất cả các khâu.

- Mỗi một nhóm tổ chức lại có những ưu tiên đầu tư khác nhau. Hiểu rõ các ưu tiên đầu tư này không những có thể giúp Chính phủ sử dụng các nguồn hỗ trợ một cách hiệu quả, tránh chồng chéo đồng thời xây dựng chiến lược huy động vốn cho ngành lâm nghiệp đối với các bên phù hợp hơn.

\section{Mở đầu}

Ngành lâm nghiệp đóng vai trò quan trọng trong việc đóng góp vào phát triển kinh tế xã hội của Việt Nam cũng như giảm thiểu và thích ứng đối với biến đổi khí hậu. Tiềm năng phát triển của ngành lâm nghiệp là rất lớn nhưng một trong những khó khăn của ngành là đảm bảo nguồn tài chính đầy đủ và bền vững để thực hiện hiệu quả công tác bảo vệ và phát triển rừng. Nguồn hỗ trợ tài chính và kĩ thuật từ các tổ chức nước ngoài, các nhà tài trợ, khối tư nhân và cộng đồng phi chính phủ trong và ngoài nước luôn đóng vai trò quan trọng trong việc cung cấp, bổ sung nguồn lực cho Việt Nam thực hiện các chương trình chính sách và cam kết quốc tế. Tuy nhiên cho tới nay, 
có rất ít các nghiên cứu, phân tích về xu thế ưu tiên và đầu tư trong lĩnh vực lâm nghiệp của các bên liên quan cũng như đưa ra bức tranh toàn diện về cơ hội và thách thức của xu thế này. Tóm lược chính sách này nhằm giải quyết thiếu hụt những thông tin đó thông qua việc trả lời 3 câu hỏi chính:

- Lĩnh vực quan tâm đầu tư của các bên nói chung và các tổ chức quốc tế, các nhà tài trợ nói riêng đối với ngành lâm nghiệp của Việt Nam trong giai đoan 2011- 2019?

- Lĩnh vực hoạt động nào còn đang thiếu nguồn tài chính từ các bên để hỗ trợ ngành lâm nghiệp Việt Nam phát triển?

- Cơ hội và thách thức của các bên trong việc cung cấp hỗ trợ tài chính và kĩ thuật triển khai các hoạt động bảo vệ và phát triển rừng tại Việt Nam?

Tóm lược chính sách này dựa trên kết quả nghiên cứu của dự án Nghiên cứu so sánh toàn cầu về REDD+ (GCS-REDD+) do NORAD tài trợ cho CIFOR từ năm 2009 - 2020. Nghiên cứu này thu thập số liệu từ năm 2011- 2019 của các bên có liên quan tại Việt Nam về lĩnh vực ưu tiên đầu tư của họ, cũng như các cơ hội và thách thức để thực hiện các hoạt động bảo vệ và phát triển rừng tại Việt Nam. Trong giai đoạn 2011- 2019, chúng tôi tiến hành nghiên cứu và thu thập số liệu tại 3 thời điểm (2011-2012; 2015-2016; 2018-2019) để phân tích xu thế ưu tiên đầu tư của các bên có liên quan. Dựa trên tài liệu thứ cấp, phỏng vấn nhóm chuyên gia, hội thảo tham vấn, nhóm nghiên cứu xác định và phỏng vấn 52 tổ chức năm 2011-2012; 51 tổ chức năm 2015-2016 và 28 tổ chức năm 2018-2019 có các hỗ trợ tài chính, kĩ thuật quan trọng cho phát triển lâm nghiệp tại Việt Nam. Các tổ chức này thuộc 5 nhóm chính: nhà tài trợ là chính phủ nước ngoài và cơ quan liên chính phủ, doanh nghiệp trong và ngoài nước, tổ chức phi chính phủ trong và ngoài nước, cơ quan chính phủ, tổ chức nghiên cứu trong và ngoài nước. Số lượng tổ chức khảo sát năm 2018-2019 (28 tổ chức) giảm hẳn so với giai đoạn trước (52 tổ chức năm 2011- 2012; 51 tổ chức năm 2015- 2016) bởi có nhiều tổ chức quốc tế, phi chính phủ và các nhà tài trợ đã từng hoạt động tại Việt Nam những năm 2011- 2012 nhưng hiện nay không còn tiếp tục hoạt động trong lĩnh vực lâm nghiệp nữa. Chính bởi vậy dù số lượng các tổ chức khảo sát năm 2018-2019 có ít hơn, kết quả nghiên cứu vẫn thể hiện đúng và toàn diện bức tranh về quan tâm và đầu tư của các bên hiện đang hoạt động tại Việt Nam.

\section{Các ưu tiên đầu tư và lĩnh vực quan tâm của các bên có liên quan}

Kết quả nghiên cứu cho thấy các bên có liên quan trong lĩnh vực bảo vệ và phát triển rừng giai đoạn 2011- 2019 tập trung vào 16 lĩnh vực chính: 1. Bảo tồn; 2. Gia tăng trữ lượng các-bon (vd. tái sinh rừng); 3. Khai thác rừng bền vững (vd. cấp chứng chỉ); 4 . Trồng mới và tái trồng rừng; 5 . Giảm phát thải đất nông nghiệp (vd. nông nghiệp xanh, cam kết không phá rừng); 6. Thiết kế chính sách và chương trình REDD+ cấp quốc gia; 7. Thiết kế chính sách và chương trình REDD+ cấp tỉnh; 8. Thực hiện chương trình REDD+ (MRV, biện pháp đảm bảo an toàn); 9. Thí điểm REDD+; 10. Quyền sở hữu; 11. Bảo tồn đa dạng sinh học; 12. Xóa đói giảm nghèo; 13. Quản trị lâm nghiệp (khai thác bất hợp pháp, chống tham nhũng); 14. Lâm nghiệp cộng đồng, đồng quản lí; 15. Thích ứng với biến đổi khí hậu; 16. Buôn bán và thương mại các-bon (Bảng 1).

Nhìn chung, các ưu tiên đầu tư nguồn lực của các bên dành cho 16 lĩnh vực này phần lớn tăng lên và mở rộng theo thời gian để mở rộng và bắt kịp với xu thế phát triển của ngành lâm nghiệp trên thế giới. Các lĩnh vực như xoá đói giảm nghèo, quản trị lâm nghiệp và bảo tồn đa dạng sinh học, giảm phát thải từ sử dụng đất lâm nghiệp và khai thác rừng bền vững, thiết kế và thực hiện REDD+ nhận được sự quan tâm cao nhất của các bên. Vấn đề về quyền sở hữu và khai thác rừng bền vững tuy có mức ưu tiên tăng lên hạn chế nhưng vẫn là vấn đề ưu tiên đầu tư then chốt của phần lớn các tổ chức được khảo sát. Mức độ ưu tiên và đầu tư của các bên dành cho lĩnh vực trồng mới rừng và tái trồng rừng đã giảm dần theo thời gian.

Nhiều lĩnh vực trước đây chiếm tỉ trọng lớn trong tổng đầu tư về thời gian và ngân sách nay đã không còn được ưu tiên bởi các bên liên quan. Ví dụ như đối với lĩnh vực bảo tồn rừng, năm 2011-2012, có 55\% các tổ chức cho biết các nguồn lực cho việc bảo tồn rừng chiếm tỉ trọng từ 50-100\% trong tổng đầu tư và thời gian của họ trong khi đến năm 2019, không còn tổ chức nào dành trên $50 \%$ tổng ngân sách và thời gian của họ cho lĩnh vực này.

Tương tự như vậy, đối với lĩnh vực trồng mới và tái trồng rừng, năm 2011-2012, có 40\% tổ chức phỏng vấn cho rằng họ đã ưu tiên 50-80\% nguồn lực của họ để 
Bảng 1. Lĩnh vực ưu tiên đầu tư và hỗ trợ ngành lâm nghiệp của các bên

\begin{tabular}{|c|c|c|c|c|}
\hline Lĩnh vực ưu tiên & 2011-2012 & 2015- 2016 & 2018- 2019 & $\begin{array}{l}\text { Tăng giảm } \\
\text { 2019-2011 }\end{array}$ \\
\hline 1. Bảo tồn & $52 \%$ & $53 \%$ & $66 \%$ & $14 \%$ \\
\hline 2. Gia tăng trữ lượng các-bon (vd. tái sinh rừng) & $42 \%$ & $37 \%$ & $72 \%$ & $30 \%$ \\
\hline Khai thác rừng bền vững (vd. cấp chứng chỉ) & $33 \%$ & $39 \%$ & $38 \%$ & $5 \%$ \\
\hline 4. Trồng mới và tái trồng rừng & $48 \%$ & $45 \%$ & $45 \%$ & $-3 \%$ \\
\hline $\begin{array}{l}\text { 5. Giảm phát thải đất nông nghiệp (vd. nông nghiệp xanh, } \\
\text { cam kết không phá rừng) }\end{array}$ & $31 \%$ & $31 \%$ & $66 \%$ & $35 \%$ \\
\hline 6. Thiết kế chính sách và chương trình REDD+ cấp quốc gia & $46 \%$ & $55 \%$ & $59 \%$ & $12 \%$ \\
\hline 7. Thiết kế chính sách và chương trình REDD+ cấp tỉnh & $58 \%$ & $49 \%$ & $59 \%$ & $1 \%$ \\
\hline $\begin{array}{l}\text { 8. Thực hiện chương trình REDD+ (MRV, biện pháp đảm } \\
\text { bảo an toàn) }\end{array}$ & $42 \%$ & $37 \%$ & $59 \%$ & $16 \%$ \\
\hline 9. Thí điểm REDD+ & $50 \%$ & $49 \%$ & $59 \%$ & $9 \%$ \\
\hline 10. Quyền sở hữu & $52 \%$ & $47 \%$ & $55 \%$ & $3 \%$ \\
\hline 11. Bảo tồn đa dạng sinh học & $37 \%$ & $43 \%$ & $72 \%$ & $36 \%$ \\
\hline 12. Xóa đói giảm nghèo & $13 \%$ & $45 \%$ & $69 \%$ & $56 \%$ \\
\hline $\begin{array}{l}\text { 13. Quản trị lâm nghiệp (khai thác bất hợp pháp, chống } \\
\text { tham nhũng) }\end{array}$ & $33 \%$ & $53 \%$ & $79 \%$ & $47 \%$ \\
\hline 14. Lâm nghiệp cộng đông, đồng quản lí & $37 \%$ & $49 \%$ & $66 \%$ & $29 \%$ \\
\hline 15. Thích ứng với biến đổi khí hậu & $40 \%$ & $41 \%$ & $69 \%$ & $29 \%$ \\
\hline 16. Buôn bán và thương mại các-bon & $29 \%$ & $18 \%$ & $45 \%$ & $16 \%$ \\
\hline
\end{tabular}

thực hiện trồng mới và tái sinh rừng nhưng đến năm 2018-2019, không còn tổ chức nào chia sẻ rằng đây vẫn là ưu tiên của họ. Số lượng các tổ chức ưu tiên trên $50 \%$ ngân sách và thời gian của họ để thực hiện các hoạt động thí điểm REDD+ cũng giảm từ $75 \%$ số tổ chức vào năm 2011-2012 xuống chỉ còn $50 \%$ số tổ chức vào năm 2018-2019. Nếu như 100\% các tổ chức khảo sát năm 2015-2016 chia sẻ họ đã ưu tiên sử dụng trên 50\% ngân sách và thời gian của họ để thực hiện các hoạt động liên quan đến buôn bán và thương mại các-bon thì đến năm 2018-2019, không còn tổ chức nào dành quá $50 \%$ ngân sách và nguồn lực của họ để làm vấn đề này nữa.

Ngược lại, vào năm 2011-2012, không có tổ chức nào khẳng định họ đang ưu tiên trên $50 \%$ thời gian và ngân sách vào lĩnh vực gia tăng trữ lượng các-bon. Tuy vậy vào năm 2018-2019, có trên 50\% tổ chức tham gia nghiên cứu cho biết họ ưu tiên dành từ $50-80 \%$ thời gian và nguồn lực của họ cho lĩnh vực này.
Thiết kế chính sách và thực hiện chương trình REDD+ quốc gia cũng là lĩnh vực nhận được nhiều ưu tiên nhất. Năm 2011-2012, chỉ có 33\% tổ chức khảo sát cho rằng họ đang sử dụng trên $50 \%$ nguồn tài chính và nhân lực của họ để thực hiện các chương trình REDD+ quốc gia. Nhưng con số này đã tăng lên là $66 \%$ tổ chức khảo sát năm 2015-2016 và $60 \%$ năm 2019- 2020. Số lượng các tổ chức cho biết họ ưu tiên trên $50 \%$ ngân sách của họ dành cho lĩnh vực quyền sử dụng đất cũng tăng từ $57 \%$ tổ chức khảo sát năm 2011-2012 lên đến 100\% tổ chức khảo sát năm 2019- 2020.

Trong khi một số lĩnh vực như xóa đói giảm nghèo, quản trị lâm nghiệp luôn nhận được ưu tiên ổn định trong 10 năm với trên $50 \%$ nguồn lực của các tổ chức, một số lĩnh vực khác như bảo tồn đa dạng sinh học, lâm nghiệp cộng đồng, thích ứng với biến đổi khí hậu chưa bao giờ nhận được quá 33\% tổng ngân sách và nguồn lực của các tổ chức khảo sát. 
Buôn bán và thương mại các-bon

Thích ứng với biến đổi khí hậu

Lâm nghiệp cộng đồng, đồng quản lý

Quản trị lâm nghiệp (khai thác bất hợp pháp, chống...

Xoá đói giảm nghèo

Bảo tồn đa dạng sinh học

Quyền sở hữu

Thí điểm REDD+

Thực hiện chương trình REDD+ (MRV, biện ...

Thiết kế chính sách và chương trình REDD+ cấp ...

Thiết kế chính sách và chương trình REDD+ cấp ...

Giảm phát thải đất nông nghiệp (vd: nông nghiệp ...

Trồng mới và tái trồng rừng

Khai thác rừng bền vữn $\mathrm{g}$ (vd: cấp chứng chỉ)

Gia tăng trữ lượng các-bon từ tái sinh rừng

Bảo tồn rừng
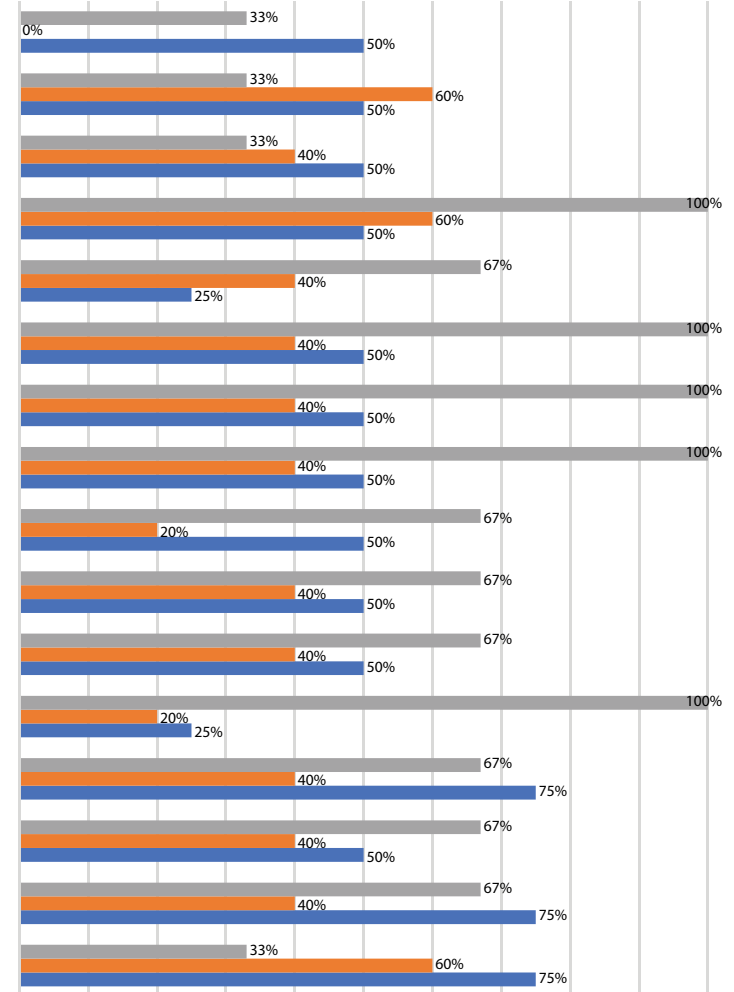

$\begin{array}{lllllllllll}0 \% & 10 \% & 20 \% & 30 \% & 40 \% & 50 \% & 60 \% & 70 \% & 80 \% & 90 \% & 100 \%\end{array}$

$2018-2019(\mathrm{~N}=3) \quad 2015-2016(\mathrm{~N}=5) \quad \square 2011-2012(\mathrm{~N}=4)$

Hình 1. Lĩnh vực ưu tiên đầu tư và hỗ trợ ngành lâm nghiệp của các nhà tài trợ là chính phủ nước ngoài.

Kết quả nghiên cứu cũng cho thấy các nhóm tổ chức khác nhau sẽ có các mối quan tâm và ưu tiên đầu tư khác nhau.

\section{Nhà tài trợ là chính phủ nước ngoài và nhà tài trợ là các tổ chức liên chính phủ}

Hình 1 và Hình 2 cho thấy hai xu thế đầu tư và mối quan tâm của các nhà tài trợ là chính phủ nước ngoài và nhà tài trợ là tổ chức liên chính phủ đối với ngành lâm nghiệp Việt Nam:

- Uu tiên và mối quan tâm về các lĩnh vực giảm phát thải sử dụng đất nông nghiệp, thiết kế và thực hiện chương trình REDD+ quốc gia, xây dựng các biện pháp và chính sách đảm bảo an toàn, bảo tồn đa dạng sinh học, nâng cao quản trị lâm nghiệp và xóa đói giảm nghèo. Các ưu tiên và mối quan tâm này nhằm bắt kịp với xu thế phát triển lâm nghiệp trên thế giới cũng như yêu cầu đặt ra của các công ước và chính sách biến đổi khí hậu trên toàn cầu như Thỏa thuận Paris. Các nhà tài trợ cũng tập trung hỗ trợ chính sách hạn chế nguyên nhân phá rừng và suy thoái rừng một cách toàn diện và hiệu quả hơn thông qua việc giải quyết các lĩnh vực ngoài ngành lâm nghiệp (ví dụ: nông nghiệp)

- Lĩnh vực phát triển thị trường thương mại các-bon, bảo tồn rừng, trồng mới và tái trồng rừng, gia tăng trữ lượng các-bon rừng vào giai đoạn 2018-2019 nhận được ít sự quan tâm và ưu tiên của các nhà tài trợ so với giai đoạn 2011-2012. Theo các bên tham gia phỏng vấn, việc giảm ưu tiên cho các lĩnh vực này là do lo ngại thị trường các-bon không có tiềm năng phát triển đồng thời các đầu tư hỗ trợ tài chính cho các lĩnh vực bảo tồn, gia tăng trữ lượng các-bon đã có nhiều tài trợ trong một thập kỉ qua.

Tuy nhiên, nếu như mối quan tâm và ưu tiên của các nhà tài trợ là chính phủ nước ngoài đối với lĩnh vực lâm nghiệp cộng đồng có phần giảm đi thì mối quan tâm của các nhà tài trợ là liên chính phủ đối với lĩnh vực này ngày càng gia tăng. Thay vào đó, ưu tiên đầu tư để giải quyết các vấn đề sở hữu đất đai đang ngày càng nhận được sự quan tâm và ưu tiên của các nhà tài trợ là chính phủ nước ngoài, thì ưu tiên của các nhà tài trợ liên chính phủ lại giảm dần theo thời gian. 


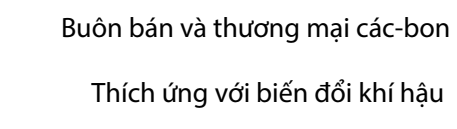

Lâm nghiệp cộng đồng, đồng quản lý

Quản trị lâm nghiệp (khai thác bất hợp pháp, chống ...

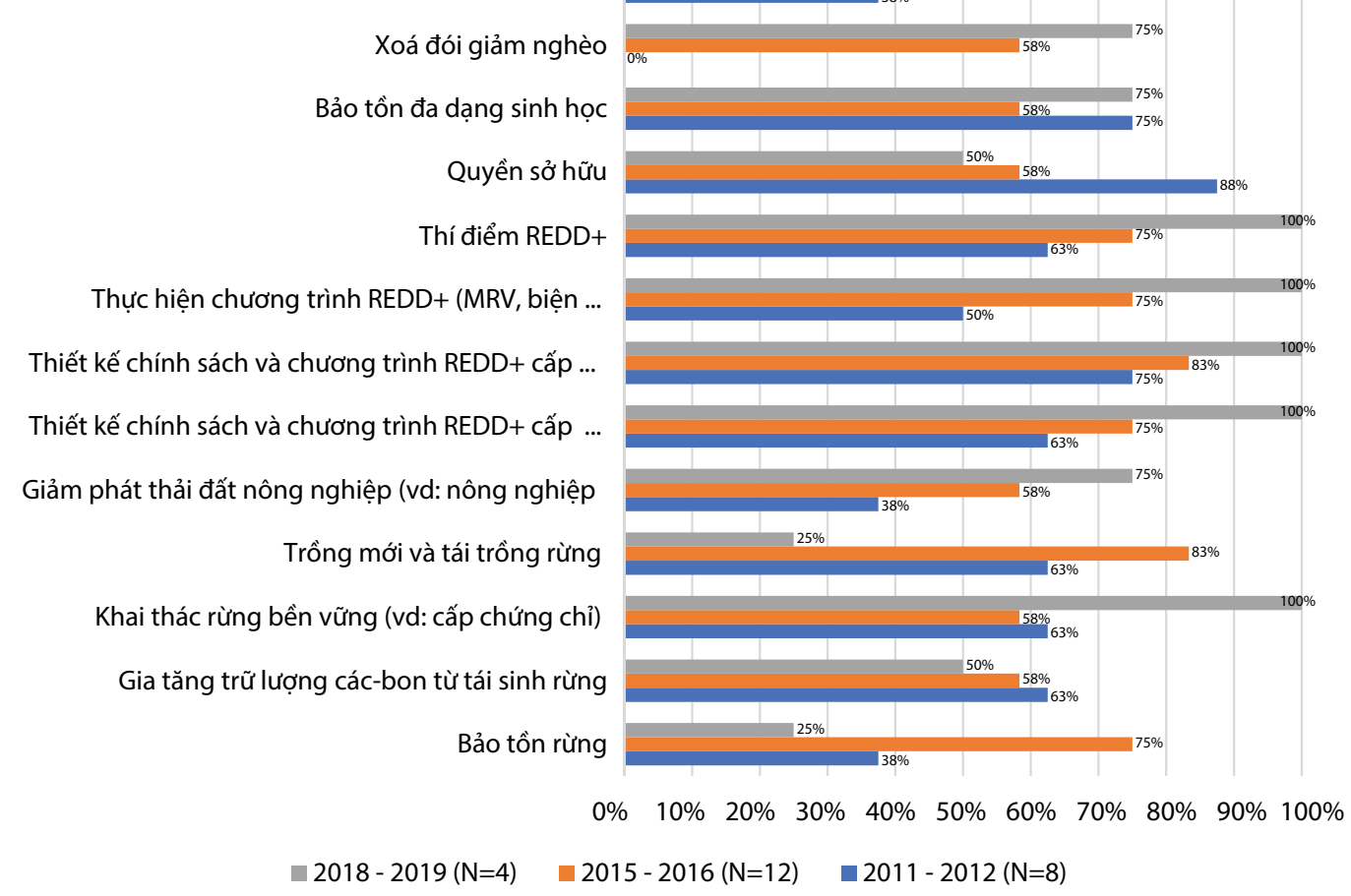

Hình 2. Lĩnh vực ưu tiên đầu tư và hỗ trợ ngành lâm nghiệp của các nhà tài trợ là các tổ chức liên chính phủ.

\section{Khối tư nhân trong và ngoài nước}

Hình 3 thể hiện thay đổi của sự quan tâm và ưu tiên của các doanh nghiệp trong nước tham gia nghiên cứu qua các năm.

Nếu như năm 2011-2012, các doanh nghiệp trong nước tham gia nghiên cứu tập trung ưu tiên vào lĩnh vực bảo tồn, trồng mới và tái sinh rừng, hỗ trợ thí điểm các dự án và chương trình REDD+, năm 2015-2016 họ tập trung ưu tiên đầu tư vào lĩnh vực cấp chứng chỉ quản lí rừng bền vững, giảm phát thải trong sử dụng đất lâm nghiệp. Tới năm 2018-2019, các doanh nghiệp trong nước tham gia nghiên cứu này lại đặt ưu tiên đầu tư của mình vào các lĩnh vực thích ứng với biến đổi khí hậu, chống khai thác gỗ bất hợp pháp và xóa đói giảm nghèo. Sự thay đổi các mục tiêu ưu tiên này được các bên tham gia nghiên cứu lí giải bởi các lí do sau. Thứ nhất, những rào cản pháp lí và chính sách (ví dụ: chưa rõ ràng về quyền sử dụng đất, quyền các-bon) khiến các doanh nghiệp ngần ngại trong việc đầu tư vào bảo vệ và phát triển rừng, thời gian 10 năm vừa qua, các doanh nghiệp thử nghiệm các lĩnh vực khác nhau chứ không cố định ở một lĩnh vực cụ thể nào để tìm kiếm cơ hội trong tương lai. Thứ hai, áp lực đối với các doanh nghiệp thực hiện mô hình sản xuất xanh, thân thiện với môi trường, trách nhiệm xã hội ngày càng gia tăng, dẫn đến các ưu tiên trong lĩnh vực này cũng tăng lên theo thời gian.

Đối với khối tư nhân đến từ nước ngoài, nhóm nghiên cứu gặp nhiều khó khăn trong việc tiếp cận các doanh nghiệp do chủ yếu các công ty này không có trụ sở chính ở Việt Nam và chính sách chia sẻ thông tin của họ hạn chế sự tham gia trong nghiên cứu này. Mặc dù cần có nhiều nghiên cứu trong tương lai để giải quyết thiếu hụt thông tin liên quan đến lĩnh vực này, kết quả của nhóm nghiên cứu cho thấy đối với một mẫu nghiên cứu nhỏ, các doanh nghiệp nước ngoài có mối quan tâm và ưu tiên tới các lĩnh vực rộng hơn các doanh nghiệp trong nước. Tuy nhiên, theo như trao đổi của các doanh nghiệp này, họ chủ yếu muốn tiến hành thí điểm để khẳng định tiềm năng đầu tư vào thị trường Việt Nam. Cũng giống như các doanh nghiệp trong nước, các doanh nghiệp ngoài nước tham gia phỏng vấn cũng đề cập đến những rào cản chính sách là nguyên nhân chính dẫn đến việc họ chưa mở rộng đầu tư vào Việt Nam. 
Buôn bán và thương mại các-bon

Thích ứng với biến đổi khí hậu Lâm nghiệp cộng đồng, đồng quản lý Quản trị lâm nghiệp (khai thác bất hợp pháp, chống ...

Xoá đói giảm nghèo Bảo tồn đa dạng sinh học Quyền sở hữu Thí điểm REDD+

Thực hiện chương trình REDD+ (MRV, biện ... Thiết kế chính sách và chương trình REDD+ cấp ... Thiết kế chính sách và chương trình REDD+ cấp ... Giảm phát thải đất nông nghiệp (vd: nông nghiệp ... Trồng mới và tái trồng rừng Khai thác rừng bền vững (vd: cấp chứng chỉ) Gia tăng trữ lượng các-bon từ tái sinh rừng Bảo tồn rừng
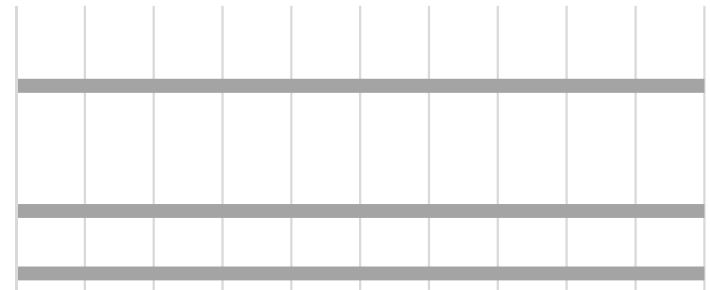
(1) . 
Buôn bán và thương mại các-bon

Thích ứng với biến đổi khí hậu

Lâm nghiệp cộng đồng, đồng quản lý

Quản trị lâm nghiệp (khai thác bất hợp pháp, chống ...

Xoá đói giảm nghèo

Bảo tồn đa dạng sinh học

Quyền sở hữu

Thí điểm REDD+

Thức hiên chương trình REDD+ (MRV, biên pháp đảm bảo an toàn

Thiết kế chính sách và chương trình REDD+ cấp tỉnh

Thiết kế chính sách và chương trình REDD+ cấp quốc gia

Giảm phát thải đất nông nghiệp (vd: nông nghiêp xanh, cam kết không phá rừng)

Trồng mới và tái trồng rừng

Khai thác rừng bền vững (vd: cấp chứng chỉ)

Gia tăng trữ lượng các-bon từ tái sinh rừng

Bảo tồn rừng
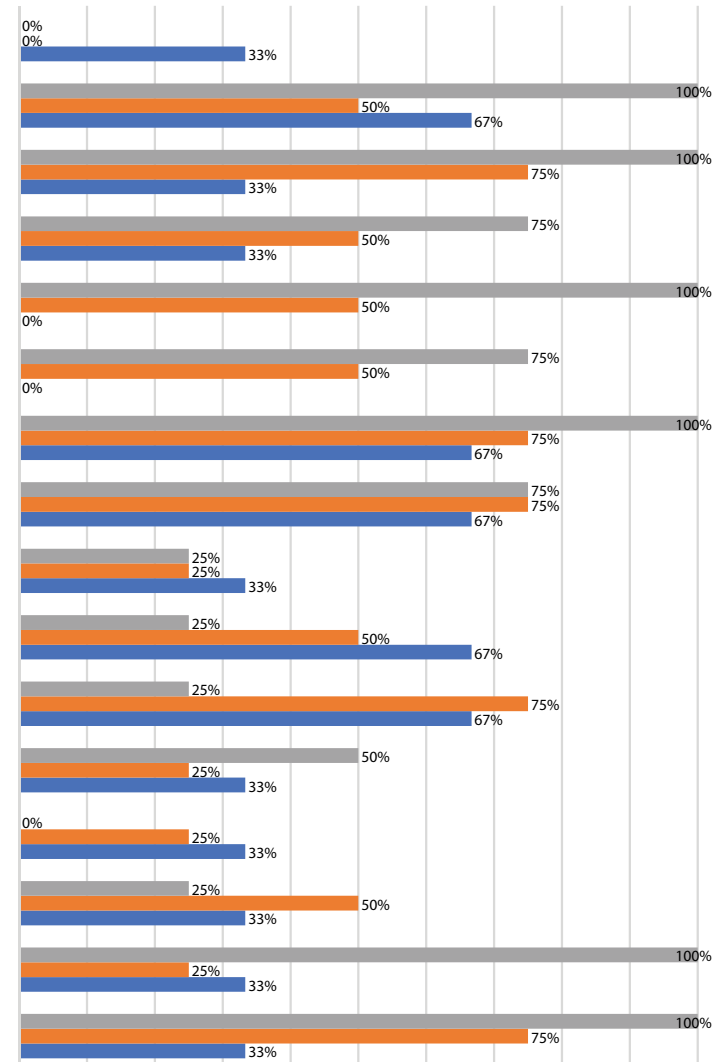

$\begin{array}{lllllllllllll}0 & 0 & 10 \% & 20 \% & 30 \% & 40 \% & 50 \% & 60 \% & 70 \% & 80 \% & 90 \% & 100 \%\end{array}$

$2018-2019(\mathrm{~N}=4) \quad \square 2015-2016(\mathrm{~N}=4) \quad \square 2011-2012(\mathrm{~N}=3)$

Hình 5. Lĩnh vực ưu tiên đầu tư và hỗ trợ ngành lâm nghiệp của các tổ chức phi chính phủ trong nước.

\section{Tổ chức phi chính phủ trong và ngoài nước}

Hình 5 cho thấy bức tranh toàn cảnh và thay đổi ưu tiên của các tổ chức phi chính phủ trong nước đối với các lĩnh vực bảo vệ và phát triển rừng. Ngoại trừ các lĩnh vực liên quan đến REDD+, tái trồng rừng và khai thác rừng bền vững, buôn bán và thương mại các-bon ngày càng nhận được ít quan tâm của các tổ chức phi chính phủ trong nước, tất cả các lĩnh vực còn lại đều nhận được nhiều hơn sự quan tâm và đầu tư của nhóm đơn vị này. Việc giảm bớt ưu tiên trong các lĩnh vực như REDD+ chủ yếu do các dự án và chương trình dự án mà những tổ chức phi chính phủ trong nước này nhận được đã hết, trong khi đó nguồn tài chính mà các tổ chức này được tài trợ ngày càng chú trọng vào các lĩnh vực khác, như thích ứng với biến đổi khí hậu, giảm phát thải với sử dụng đất nông nghiệp.

Khác với các tổ chức NGO trong nước, các tổ chức NGO nước ngoài đều thể hiện sự quan tâm rộng rãi hơn theo thời gian với tất cả các lĩnh vực lâm nghiệp trong Bảng 1. Chỉ có hai lĩnh vực: thí điểm REDD+ và thực hiện chương trình REDD+ nhận được ít sự quan tâm hơn từ các tổ chức NGO nước ngoài (Hình 6). Ngoài ra, nếu như các tổ chức NGO trong nước không còn ưu tiên REDD+ do nguồn tài chính hỗ trợ cho thực hiện hoạt động này đã hết, thì các tổ chức NGO nước ngoài vẫn ưu tiên rất nhiều cho hoạt động REDD+ đặc biệt là hỗ trợ thực hiện REDD+ ở cấp tỉnh.

\section{Cơ quan nhà nước}

Hình 7 cho thấy các ưu tiên đầu tư và hỗ trợ của các cơ quan nhà nước tăng dần theo thời gian. Đặc biệt, hoạt động giảm phát thải đất nông nghiệp, thực hiện chương trình REDD+, bảo tồn đa dạng sinh học, xoá đói giảm nghèo, quản trị lâm nghiệp, thích ứng với biến đổi khí hậu, và buôn bán thương mại các-bon đều nhận được sự quan tâm ngày càng tăng của các cơ quan chính phủ. Đáng chú ý, một số các ưu tiên đầu tư đã có chiều hướng giảm trong giai đoạn 2015-2016 (ví dụ như MRV, giảm phát thải; mua bán các-bon), nhưng sự ưu tiên vượt bậc lại được phục hồi vào giai đoạn 2018-2019. Việc quan tâm tới các lĩnh vực toàn diện của ngành ngày càng tăng một mặt thể hiện những 


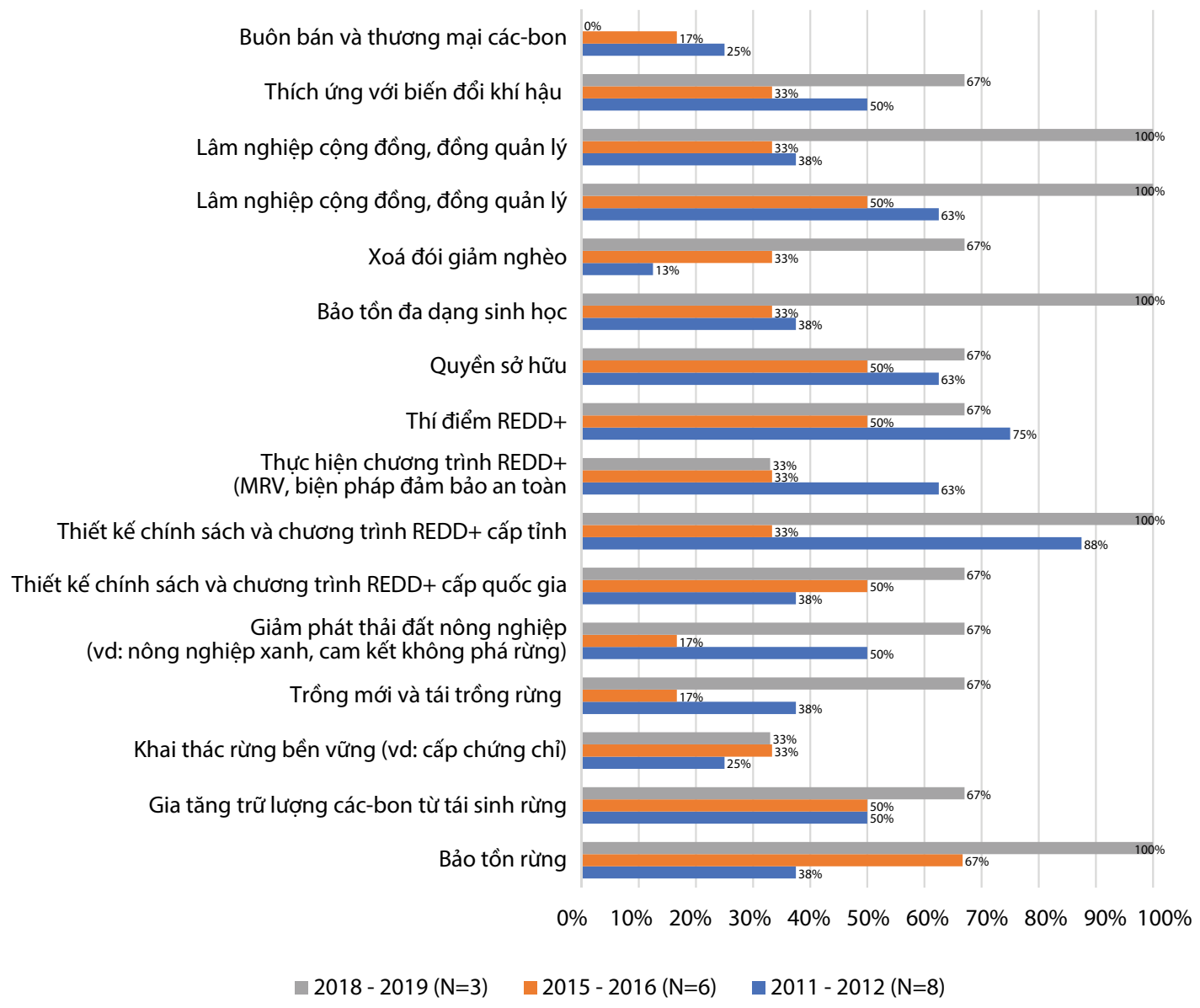

Hình 6. Lĩnh vực ưu tiên đầu tư và hỗ trợ ngành lâm nghiệp của các tổ chức phi chính phủ nước ngoài.

yêu cầu quốc tế mới mà Việt Nam buộc phải tuân thủ và thực hiện cam kết, dẫn tới việc các nhà hoạch định chính sách cũng đặt nhiều ưu tiên hơn. Mặt khác, trong bối cảnh hiện đại hóa ngành lâm nghiệp đã xuất hiện nhiều vấn đề mới (ví dụ nguồn tài chính mới cho ngành từ việc chi trả dịch vụ các-bon) cần tháo gỡ để ngành có thể phát triển toàn diện hơn.

\section{Tổ chức nghiên cứu trong và ngoài nước}

Trong thời gian 10 năm trở lại đây, các ưu tiên trong lĩnh vực nghiên cứu của các tổ chức nghiên cứu trong nước hiện nay đang ngày càng tập trung vào gia tăng trữ lượng từ tái sinh rừng, thực hiện thí điểm REDD+ tại cấp tỉnh và thực hiện chương trình REDD+ quốc gia, giảm phát thải từ sử dụng đất nông nghiệp, lâm nghiệp cộng đồng, thích ứng với biến đổi khí hậu và quản lí sử dụng rừng bền vững (khai thác rừng bền vững, cam kết không phá rừng và suy thoái rừng) (Hình 8). Trong khi đó, các tổ chức nghiên cứu nước ngoài lại đang ưu tiên vào lĩnh vực thực hiện REDD+, đảm bảo quyền sử dụng, gia tăng trữ lượng các-bon và bảo tồn rừng (Hình
9). Mặc dù có sự thay đổi về mức độ ưu tiên đối với từng lĩnh vực, cả tổ chức nghiên cứu trong nước và ngoài nước đều ưu tiên nghiên cứu tất cả các vấn đề liên quan đến bảo vệ và phát triển rừng.

\section{Tiềm năng và cơ hội}

Tất cả các lĩnh vực phát triển lâm nghiệp đều nhận được sự quan tâm đầu tư nhiều hơn từ các bên có liên quan. Số lượng các bên coi 16 hoạt động phát triển lâm nghiệp là ưu tiên của họ ngày càng tăng. Ví dụ, nếu như năm 2011 , chỉ có $37 \%$ các bên tham gia phỏng vấn ưu tiên đầu tư vào lĩnh vực bảo tồn đa dạng sinh học thì tại thời điểm 2019 đã có $72 \%$ tổng số tổ chức phỏng vấn khẳng định lính vực này đang là lĩnh vực họ quan tâm đầu tư. Tương tự như vậy, các hỗ trợ ưu tiên đầu tư cho cải thiện quản trị lâm nghiệp chỉ là quan tâm và ưu tiên của $33 \%$ tổ chức được phỏng vấn năm 2011 nhưng con số này đã tăng lên 79\% năm 2019. Đặc biệt, các lĩnh vực chủ đạo của ngành lâm nghiệp như bảo tồn và phát triển rừng, thích ứng với biến đổi khí hậu, trồng mới và tái trồng rừng, bảo đảm quyền cho các bên có liên quan vẫn nhận 


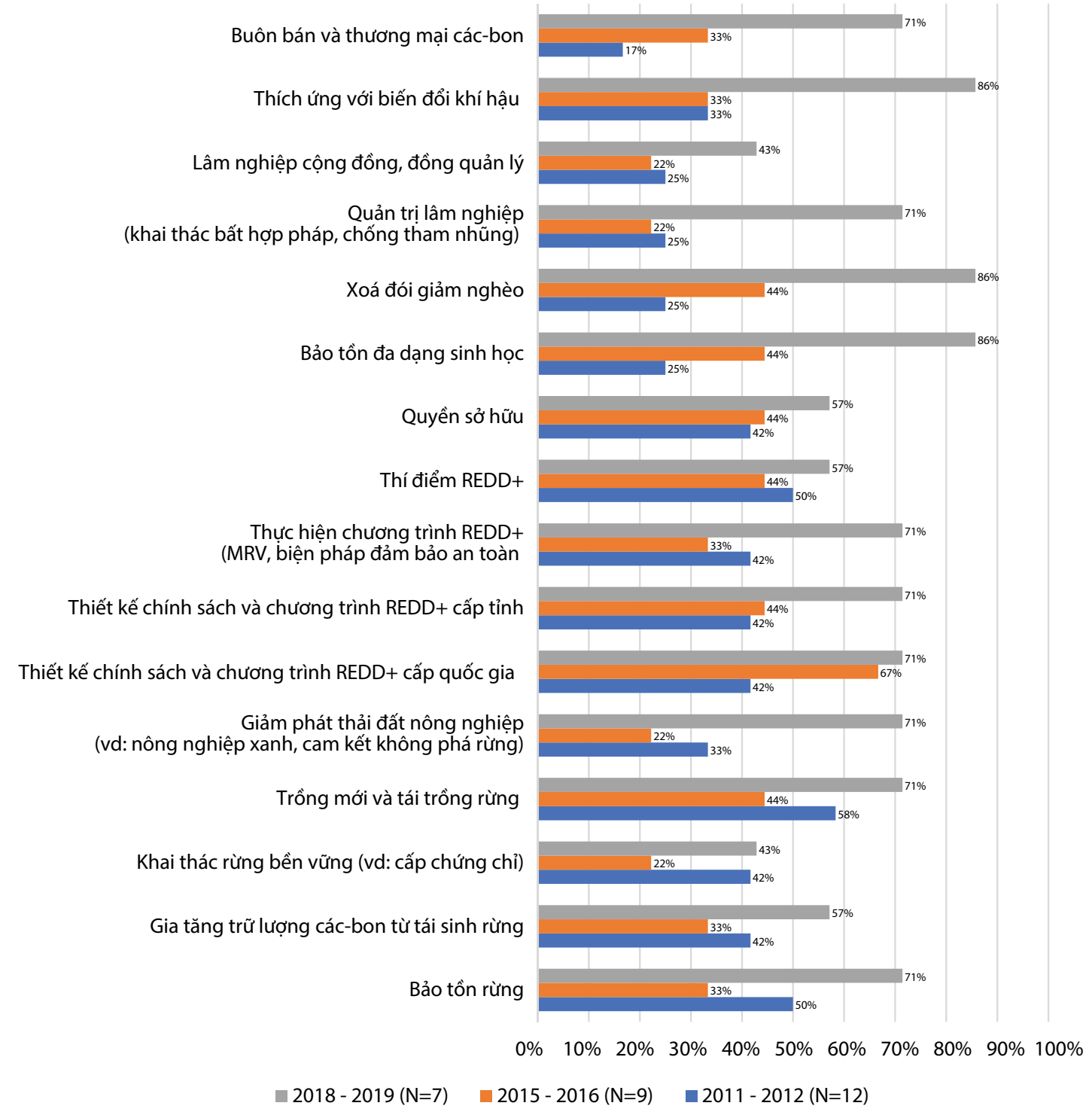

Hình 7. Lĩnh vực ưu tiên đầu tư và hỗ trợ ngành lâm nghiệp của các cơ quan nhà nước.

được đầu tư và quan tâm ổn định trong thời gian qua. Ngoài ra, nếu như năm 2010-2011, việc hài hòa hóa giữa mục tiêu phát triển lâm nghiệp và phát triển kinh tế xã hội nhận được rất ít quan tâm và ưu tiên của các bên có liên quan (13\% năm 2011), thì đến năm 20152016, lĩnh vực này đã là mối quan tâm của $45 \%$ các bên tham gia phỏng vấn và thậm chí còn tăng mạnh lên 69\% vào năm 2018-2019. Việc số lượng các hoạt động bảo tồn, bảo vệ và phát triển rừng trở thành ưu tiên và hỗ trợ của nhiều tổ chức tại Việt Nam tạo điều kiện phát triển ngành lâm nghiệp đồng đều hơn khi bảo tồn rừng và đa dạng sinh học tăng từ khoảng $50 \%$ trong các giai đoạn trước đến khoảng 70\% đối với giai đoạn 2018-2019.
Hỗ trợ tài chính cho các lĩnh vực mới. Nhiều lĩnh vực và sáng kiến tuy còn trong giai đoạn thử nghiệm và rất mới trên thế giới nhưng cũng đã nhận được nhiều đầu tư và ưu tiên của các bên có liên quan, đặc biệt là REDD+ và giảm phát thải từ ngành nông nghiệp (ví dụ: cam kết kinh doanh không phá rừng và suy thoái rừng) là ưu tiên đầu tư của 31\% các bên tham gia phỏng vấn năm 2011-2012 và 2015-2016 nhưng đã trở thanh ưu tiên hỗ trợ tài chính và đầu tư của 69\% tổ chức khảo sát năm 2018-2019.

\section{Khoảng trống đầu tư và ưu tiên}

Mặc dù các ưu tiên hỗ trợ tài chính và kĩ thuật trong khoảng thời gian từ 2011-2019 tạo một số điều kiện thuận 
Buôn bán và thương mại các-bon

Thích ứng với biến đổi khí hậu

Lâm nghiệp cộng đồng, đồng quản lý

Quản trị lâm nghiệp (khai thác bất hợp pháp, chống ...

Xoá đói giảm nghèo

Bảo tồn đa dạng sinh học

Quyền sở hữu

Thí điểm REDD+

Thực hiện chương trình REDD+ (MRV, biện ...

Thiết kế chính sách và chương trình REDD+ cấp ...

Thiết kế chính sách và chương trình REDD+ cấp ...

Giảm phát thải đất nông nghiệp (vd: nông nghiệp ...

Trồng mới và tái trồng rừng

Khai thác rừng bền vững ( $\mathrm{vd}$ : cấp chứng chỉ)

Gia tăng trữ lượng các-bon từ tái sinh rừng

Bảo tôn rừng
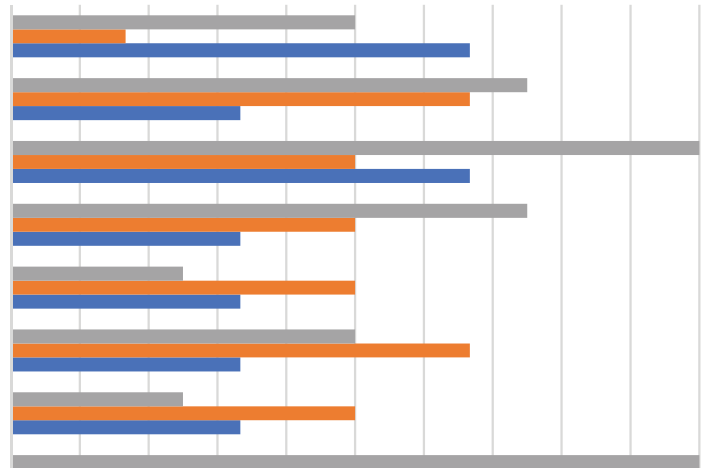

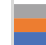

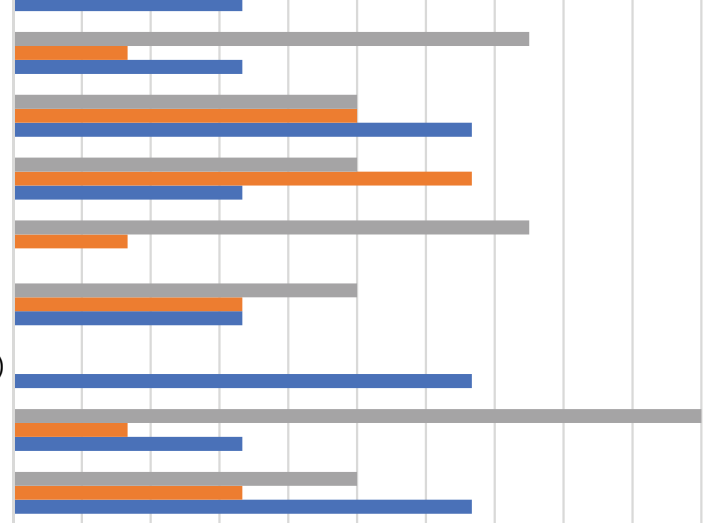

$\begin{array}{lllllllllll}0 \% & 10 \% & 20 \% & 30 \% & 40 \% & 50 \% & 60 \% & 70 \% & 80 \% & 90 \% & 100 \%\end{array}$

$2018-2019(\mathrm{~N}=4) \quad \square 2015-2016(\mathrm{~N}=6) \quad \square 2011-2012(\mathrm{~N}=3)$

Hình 8. Lĩnh vực ưu tiên của các tổ chức nghiên cứu trong nước.

Buôn bán và thương mại các-bon

Thích ứng với biến đổi khí hậu Lâm nghiệp cộng đồng, đồng quản lý

Quản trị lâm nghiệp (khai thác bất hợp pháp, chống ...

Xoá đói giảm nghèo

Bảo tồn đa dạng sinh học

Quyền sở hữu

Thí điểm REDD+

Thực hiện chương trình REDD+ (MRV, biện ...

Thiết kế chính sách và chương trình REDD+ cấp ...

Thiết kế chính sách và chương trình REDD+ cấp ...

Giảm phát thải đất nông nghiệp (vd: nông nghiệp ...

Trồng mới và tái trồng rừng

Khai thác rừng bền vững (vd: cấp chứng chỉ)

Gia tăng trữ lượng các-bon từ tái sinh rừng

Bảo tôn rừng
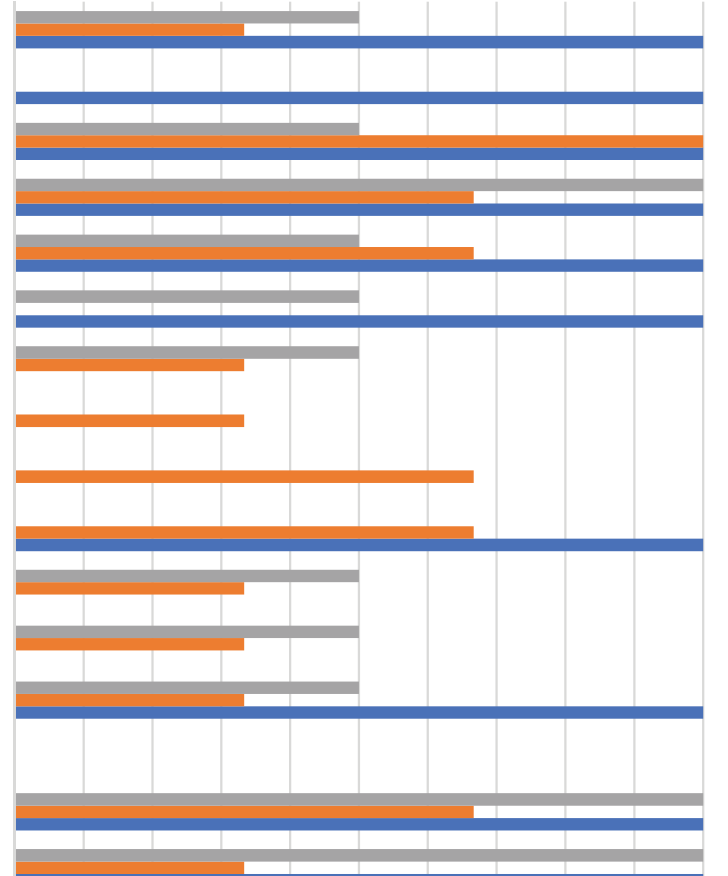

$\begin{array}{llllllllllll}0 \% & 10 \% & 20 \% & 30 \% & 40 \% & 50 \% & 60 \% & 70 \% & 80 \% & 90 \% & 100 \%\end{array}$

$\square 2018-2019(\mathrm{~N}=2) \quad \square 2015-2016(\mathrm{~N}=3) \quad \square 2011-2012(\mathrm{~N}=1)$

Hình 9. Lĩnh vực ưu tiên của các tổ chức nghiên cứu nước ngoài. 
lợi cho ngành lâm nghiệp phát triển, các ưu tiên hiện nay của các bên cũng cho thấy nhiều lĩnh vực còn đang bị bỏ ngỏ và chưa đầu tư tương xứng với tiềm năng và vai trò của lĩnh vực này.

Mua bán và thương mại các-bon. Những thảo luận quốc tế liên quan đến vai trò của rừng và ngành lâm nghiệp trong bối cảnh biến đổi khí hậu luôn gắn liền với giảm phát thải và thị trường thương mại các-bon. Tuy nhiên từ năm 2011 đến 2019, ưu tiên đầu tư, nghiên cứu, hỗ trợ, phát triển thị trường thương mại các-bon tại Việt Nam chỉ là quan tâm và ưu tiên của $29 \%$ các tổ chức được khảo sát vào giai đoạn 2011-2012, 18\% vào giai đoạn 2015- 2016 và có tăng lên 45\% vào giai đoạn 2018-2019. Trong bối cảnh Việt Nam đang thí điểm chính sách chi trả cho dịch vụ các-bon, thực hiện Chương trình REDD+ quốc gia cũng như thực hiện các cam kết giảm phát thải khí nhà kính (ví dụ: Thỏa thuận Paris) cần có nhiều hơn hỗ trợ tài chính và kĩ thuật của các bên có liên quan để Việt Nam có thể thực hiện chính sách này hiệu quả.

Uu tiên hỗ trợ về chế biến lâm sản. Chương trình chế biến gỗ và lâm sản là một trong năm chương trình của Chiến lược phát triển lâm nghiệp Việt Nam giai đoạn 2006- 2020. Tuy nhiên kết quả nghiên cứu này cho thấy các bên có liên quan chưa quan tâm và ưu tiên lĩnh vực này đầy đủ và tương xứng với vai trò của ngành chế biến gỗ và thương mại lâm sản. Việc thiếu hụt các nguồn hỗ trợ cần thiết trong lĩnh vực này cũng có thể ảnh hưởng tới tiềm năng phát triển lâu dài của ngành và do vậy cần phải được xem xét một cách kĩ lưỡng.

Hỗ trợ nghiên cứu cơ bản về lâm nghiệp. Dù các tổ chức nghiên cứu trong và ngoài nước vẫn đang nghiên cứu các lĩnh vực để phát triển ngành một cách toàn diện, kết quả điều tra cho thấy các bên không đặt ưu tiên vào việc hỗ trợ nghiên cứu. Sự thiếu hụt các hỗ trợ tài chính và kĩ thuật để tiến hành các nghiên cứu cơ bản sẽ dẫn tới việc các quyết định chính sách sẽ không được xây dựng dựa trên các thông tin và kết quả khoa học đáng tin cậy. Trong bối cảnh ngân sách nhà nước dành cho nghiên cứu khoa học ngày càng hạn hẹp và các đơn vị nghiên cứu trong nước sẽ dần phải tự chủ để tiến hành nghiên cứu thì các hỗ trợ chuyển giao khoa học kĩ thuật và hỗ trợ tài chính từ các tổ chức nước ngoài được kì vọng vì sẽ giúp các nhà hoạch định chính sách có các thông tin khoa học chính xác và kịp thời hơn.

\section{Lâm nghiệp cộng đồng ngày càng nhận được ít sự quan tâm và ưu tiên đầu tư của một số nhà tài trợ lớn. Kết} quả nghiên cứu này cũng cho thấy một số các nhà tài trợ lớn chủ lực hỗ trợ cho việc thực hiện các chính sách phát triển lâm nghiệp cộng đồng đang dần giảm sự quan tâm và ưu tiên đầu tư của mình đối với lĩnh vực này. Để thực hiện các mục tiêu đề ra của Chiến lược phát triển lâm nghiệp 2006- 2020 và Luật lâm nghiệp 2017 liên quan đến phát triển lâm nghiệp xã hội đòi hỏi có sự tập trung thường xuyên và ổn định vào lĩnh vực này.

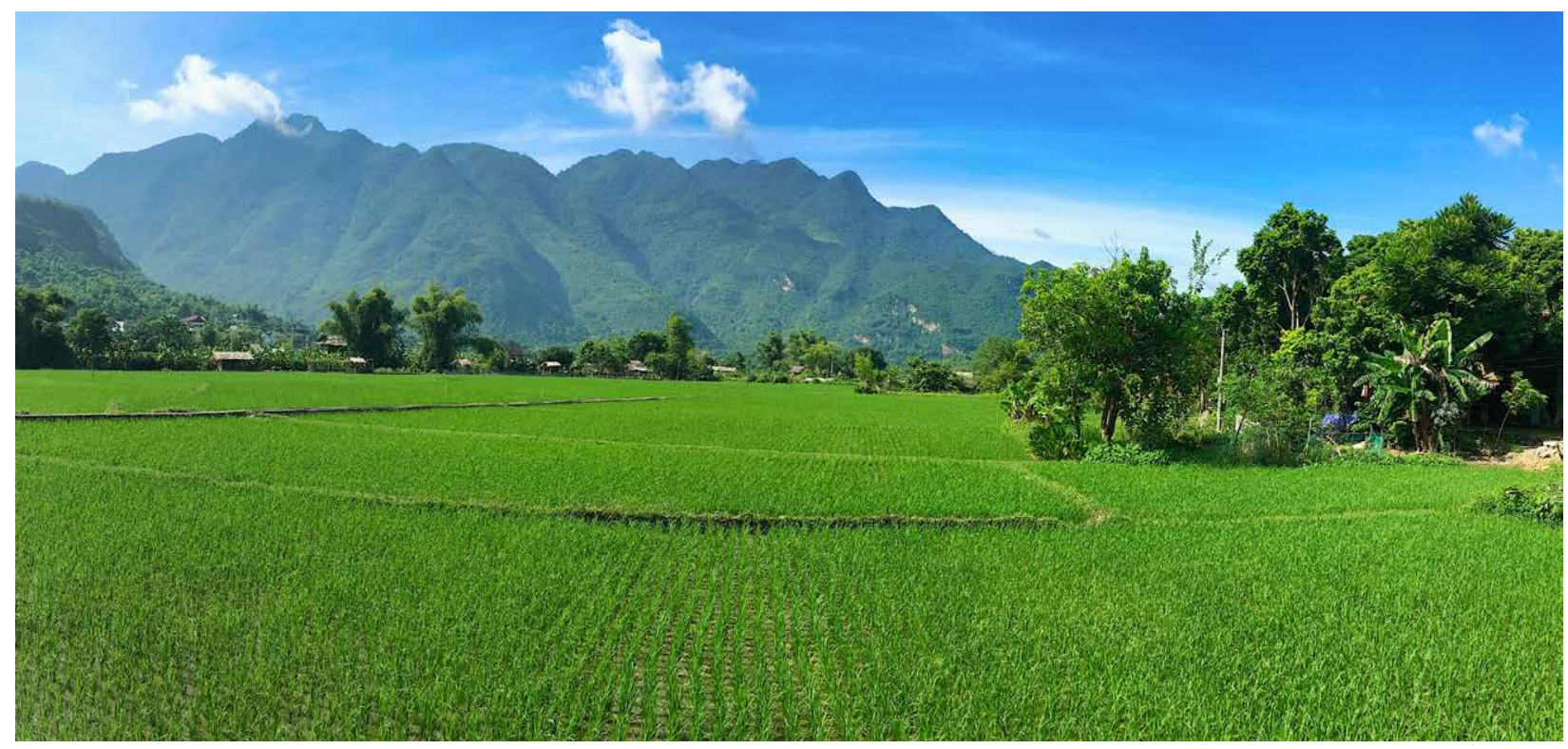

Phong cảnh rừng và đất nông nghiệp ở vùng Tây Bắc Việt Nam. Ảnh được chụp tại huyện Mai Châu, tỉnh Hoà Bình. Người chụp Hoàng Tuấn Long 
Các hỗ trợ chưa đầy đủ để phát triển ngành Lâm nghiệp toàn diện. Theo định hướng của Luật Lâm nghiệp, phát triển ngành lâm nghiệp phải toàn diện theo chuỗi từ quản lý bảo vệ, phát triển, sử dụng rừng, chế biến thương mại lâm sản. Tuy nhiên, các lĩnh vực quan tâm, ưu tiên của các bên liên quan đến nay tập trung chủ yếu cho khâu quản lý, bảo vệ rừng, và các hoạt động nghiên cứu, hỗ trợ về chính sách; REDD+; các khâu khác chưa được quan tâm, hỗ trợ. Về lĩnh vực phát triển rừng: các bên liên quan đang quan tâm đến trồng mới và tái trồng rừng; còn nhiều lĩnh vực khác như giống cây lâm nghiệp chất lượng cao; nâng cao năng suất chất lượng rừng; trồng rừng gỗ lớn; phương thức nông lâm kết hợp, liên doanh, liên kết giữa hộ gia đình với doanh nghiệp, khối tư nhân, đầu tư phát triển rừng trồng còn chưa nhận được quan tâm đúng mức. Về lĩnh vực sử dụng rừng: các ưu tiên mới quan tâm đến quản lý rừng bền vững (chứng chỉ rừng), các lĩnh vực chưa được quan tâm như phát triển lâm sản ngoài gỗ, các dịch vụ trong lâm nghiệp; phát triển du lịch sinh thái. Bên cạnh đó, việc triển khai thực hiện hiện đại hóa ngành Lâm nghiệp là yêu cầu cần thiết, phù hợp với xu thế của thế giới; việc ứng dụng khoa học công nghệ cao trong lâm nghiệp cũng chưa được quan tâm.

Việc nghiên cứu xu thế tiếp cận các nguồn tài chính cho ngành lâm nghiệp trong thời gian tới là rất quan trọng; xây dựng cơ chế, chính sách, hành lang pháp lý để triển khai thực hiện các quy định, phù hợp với các xu thế của thế giới cũng cần được quan tâm.

\section{Kết luận}

Tóm lược chính sách này cho thấy các ưu tiên đầu tư của các bên có liên quan trong lĩnh vực bảo vệ và phát triển rừng ngày càng gia tăng và mở rộng để bắt kịp với xu thế phát triển của ngành lâm nghiệp trên thế giới. Các hỗ trợ ưu tiên của các bên tạo điều kiện thuận lợi để Việt Nam thử nghiệm và tiên phong trong nhiều lĩnh vực chính sách và công nghệ mới. Các lĩnh vực như xoá đói giảm nghèo, quản trị lâm nghiệp và bảo tồn đa dạng sinh học, giảm phát thải từ sử dụng đất lâm nghiệp và khai thác rừng bền vững, thiết kế và thực hiện REDD+ nhận được sự quan tâm cao nhất của các bên. Vấn đề về quyền sở hữu và khai thác rừng bền vững tuy có mức ưu tiên tăng lên hạn chế nhưng vẫn là vấn đề ưu tiên đầu tư then chốt của phần lớn các tổ chức khảo sát. Mức độ ưu tiên và đầu tư của các bên dành cho lĩnh vực trồng mới rừng và tái trồng rừng đã giảm dần theo thời gian. Mặc dù các ưu tiên hỗ trợ tài chính và kĩ thuật từ 2011 cho tới 2019 đã tạo một số điều kiện thuận lợi cho ngành lâm nghiệp phát triển, các ưu tiên hiện nay của các bên cũng cho thấy nhiều lĩnh vực (ví dụ: lâm nghiệp cộng đồng, mua bán thương mại các-bon, chế biến lâm sản) còn đang bị bỏ ngỏ và chưa được đầu tư tương xứng với tiềm năng và vai trò của lĩnh vực này. Mỗi một nhóm tổ chức lại có những ưu tiên đầu tư khác nhau. Hiểu rõ các ưu tiên đầu tư này không những có thể giúp Chính phủ sử dụng các nguồn hỗ trợ một cách hiệu quả tránh chồng chéo đồng thời xây dựng chiến lược huy động vốn cho ngành lâm nghiệp đối với các bên phù hợp hơn.

\section{Lời cảm ơn}

Nghiên cứu này là một hợp phần của Nghiên cứu so sánh toàn cầu về REDD+ mà CIFOR đang tiến hành (www.cifor. org/gcs). Chúng tôi xin trân trọng cảm ơn hỗ trợ tài chính từ các nhà tài trợ bao gồm Cơ quan Hợp tác Phát triển $\mathrm{Na}$ Uy (NORAD), Cơ quan phát triển Mỹ (USAID) và Chương trình nghiên cứu CGIAR về rừng, cây và nông lâm kết hợp (CRP-FTA) đã hỗ trợ nghiên cứu này.
RESEARCH PROGRAM ON

Forests, Trees and Agroforestry
Chương trình nghiên cứu của CGIAR về Rừng, Cây gỗ và Nông lâm kết hợp (FTA) là chương trình phát triển nghiên cứu lớn nhất thế giới nhằm nâng cao vai trò của rừng, cây gỗ và nông lâm kết hợp với mục tiêu phát triển bền vững và đảm bảo lương thực để ứng phó với biến đổi khí hậu. CIFOR chủ trì các nghiên cứu FTA trong mối quan hệ đối tác chiến lược với Bioversity International, CATIE, CIRAD, INBAR, ICRAF và TBI.

Nghiên cứu này được hỗ trợ bởi Quỹ đối tác CGIAR: cigar.org/funders/ nghiên cứu sáng tạo, nâng cao năng lực của các bên đối tác, tích cực tham gia đối thoại với các bên liên quan để hỗ trợ định hình chính sách và thực tiễn tác động tới rừng và con người. CIFOR là tổ chức nghiên cứu thuộc liên minh CGIAR và chủ trì các chương trình nghiên cứu của CGIAR về Rừng, Cây gỗ và Nông lâm kết hợp (FTA). Trụ sở chính của CIFOR đặt tại Bogor, Indonesia và các văn phòng của CIFOR có mặt tại Nairobi, Kenya; Yaounde, Cameroon; Lima, Peru và Bonn, Germany. 